\title{
Curriculum of the Industry Revolution 4.0 and the Pandemic of Covid-19 Era
}

\author{
Arianus Adam Raja Oja ${ }^{1,}$, Mustiningsih ${ }^{1}$, Agus Timan ${ }^{1}$, Diah Kholilurrokhman ${ }^{1}$, \\ Diyah Rieka Rahmawati ${ }^{1}$, Dwi Eny Nur Faiza ${ }^{1}$ \\ ${ }^{1}$ Department of Education Administration, Universitas Negeri Malang, Malang, Indonesia \\ ${ }^{*}$ Corresponding author. Email: arry.walteruz@gmail.com
}

\begin{abstract}
The aim of this study is to describe the curriculum implementation of the Industrial Revolution 4.0 and the Covid-19 Pandemic Era and to determine the extent of the implementation process in these two eras. This study uses a literature review study method using analysis content analytic. The results of the analysis show that the implementation of the postrevised 2013 Curriculum is still very relevant to the Industrial Revolution 4.0 Era, although there are still several aspects that need to be addressed. The Emergency Curriculum (in special conditions) is a simplification of competencies that refers to the 2013 Curriculum, but it all returns to how professional teachers are in managing learning amid the Covid-19 pandemic.
\end{abstract}

Keywords: curriculum, revolution industrial 4.0, covid-19 pandemic

\section{INTRODUCTION}

The existence of the Industrial Revolution 4.0 era requires educators to be able to follow the development of science and technology which is growing very fast and be more proficient in using it as a means of learning activities to minimize the gaps in knowledge and character between teachers and students. Educators who are adept at using technology are useless without a clear curriculum. The definition of curriculum according to Law Number 20 of 2003 concerning the National Education System is a set of plans and arrangements regarding the objectives, content, and learning materials as well as methods used as guidelines for implementing learning activities to achieve certain educational goals. In Indonesia itself, the curriculum is applied to primary and secondary education is the 2013 Curriculum. The 2013 Curriculum is a science-based educational program provided by educational institutions with the aim of preparing the golden generation of the Indonesian nation, namely by encouraging students to be better at observing, trying, asking, reasoning, and presenting what they know after receiving learning material. The 2013 Curriculum also makes students play an active role in the learning process and have a critical thinking.

In the midst of implementing and optimizing the implementation of the 2013 Curriculum throughout Indonesia, it is not expected that non-natural disasters in the form of the spread of the Covid-19 pandemic have hit almost all parts of the world, without exception Indonesia. The Covid-19 pandemic has had a huge impact on the world of education in Indonesia. Nationally, 404 thousand schools were closed in Indonesia to avoid the chain of spread (Kompasiana, 2020). Suddenly formal schools are required to use distance learning media instead of face-to-face learning without proper preparation. Continuity of learning that is not implemented in schools has the potential to have a prolonged negative impact. Based on this, the Ministry of Education and Culture issued a Decree of the Minister of Education and Culture of the Republic of Indonesia Number 719/P/2020 concerning Guidelines for Implementing Curriculum in Education Units in Special Conditions. The Emergency Curriculum (In Special Conditions) prepared by the Ministry of Education and Culture is a simplification of the National Curriculum. In the curriculum, basic competencies are reduced for each subject so that teachers and students can focus on essential competencies and prerequisite competences for continuing learning at the next level.

The results of the study by Taufiq \& Rijanto (2020) show that the quality of implementation of the 2013 Curriculum is in the very good category, but it is necessary to make improvements in the preparation of learning scenarios in the learning implementation plan, especially the completeness of the sub-components in the learning plan. Furthermore, Demonika et al. (2020) say 
that some teachers already have an understanding of 13 Curriculum regarding learning tools, but some teachers still have difficulty in developing effective and efficient media and teaching materials for students. Research of Prajana \& Astuti (2020) shows that most teachers use ICT as a tool in lesson planning, but in the learning process and evaluation it is still not optimal due to limited facilities and infrastructure. Research of Subhi, (2020) states that the issuance of an emergency curriculum provides simplification of concepts and learning targets, but it all returns to how professional teachers are in managing learning amid the Covid-19 pandemic.

This study aims clicking explained on curriculum implementation of the Industrial Revolution 4.0 era and the era of pandemic Covid-19 and to determine the extent to which the process of implementing the curriculum in these two eras.

\section{METHOD}

This study uses a literature review study method. The author examines various literature on the curriculum in the Industrial Revolution 4.0 era and the Covid-19 pandemic era which is sourced from the latest scientific journal articles on the implementation of the curriculum in the Industrial Revolution 4.0 era and the Covid-19 pandemic era.

This assessment goes through the following stages: (1) literature search; (2) organizing the literature review by classifying scientific sources according to the themes and topics discussed; (3) analyzing using analysis content analytic to understand the implementation of the curriculum in the era of the Industrial Revolution 4.0 and the Covid-19 pandemic era in depth; and (4) interpreting the data and conclusions.

\section{RESULT AND DISCUSSION}

\subsection{Curriculum of the Industry Revolution 4.0 Era}

World development from time to time, continues to change. One of the factors causing this is the change in the economic order as a result of the industrial revolution. During its development, the world has passed through the stages of the industrial revolution, namely: (1) Industrial Revolution 1.0, occurred in the 18th century, marked by the invention of the steam engine, which allowed goods to be mass produced; (2) The Industrial Revolution 2.0, occurred in the 19th to 20th centuries, was marked by the use of electricity which made production costs cheap; 3) Industrial Revolution 3.0, occurred in the 1970s, marked by the use of computerization; and (4) Industrial Revolution 4.0, took place around the 2010s, marked by intelligence engineering and the internet of things as the backbone of human and machine movement and connectivity (Prasetyo \& Trisyanti, 2018).
At every stage of the industrial revolution, there must be changes in the order of human life. These changes are described clearly by Risdianto (2019), namely the steam engine that was invented in the era of the first revolution, in the 18th century has succeeded in accelerating economic growth drastically, in which the per capita income of countries in the world has grown to six times. The second revolution known as the Technological Revolution was marked by the use and production of iron and steel on a large scale; the use of steam power is expanding; invented telegraph machine; petroleum is also found and widely used; and this era is the initial period of electricity use. In the third industrial revolution, there was a shift in the manufacturing industry into a digital business which was marked by mastery of digital technology in the media and retail industries. The changes that occurred in this era were the relations and communication patterns of contemporary society, where the revolution put forward sides real time, distance and time are shortened.

Meanwhile, in the era of the Industrial Revolution 4.0 , the industrial sector underwent major changes. In almost all lines of human life, information and communication technology is optimally utilized (Risdianto, 2019). Things that mark this era include increased connectivity, interaction and advancement of digital, artificial intelligence and virtual systems (Lase, 2019). Prof. Klaus Martin Schwab, founder and Executive Chairman of the World Economic Forum was the first to introduce Revolution 4.0. In his book The Fourth Industrial Revolution (2017), this German technician and economist says that at this time, we are entering a revolution that fundamentally changes the way we live, work, and our relationships with others. Areas that have experienced breakthroughs due to the advancement of this new technology include: (1) artificial intelligence robotic; (2) nano technology; (3) biotechnology; (4) quantum computer technology; (5) blockchain (such as bitcoin); (6) internet-based technology; and (7) 3D printers (Schwab, 2017).

Risdianto (2019) describes the characteristics of the Industrial Revolution Era 4.0, namely: (1) robot automation, which means that the production process relies on robots that can work more effectively and efficiently to replace human roles; (2) 3D printers, namely the use of 3D printing machines as a development of the 2-dimensional generation; (3) Internet of the thing, namely the dynamics of human life with all its aspects controlled or connected to the internet network; and (4) Big data, which is a data system that collects information about us. This system regulates how technology works to detect, what is our favorite, then we are directed to advertisements about our preferences.

The Industrial Revolution Era 4.0 is also known as the Digital Revolution and the Era of Technology Disruption (Ghufron, 2018). In the Indonesian Dictionary (KBBI), 
disruption means being uprooted from the root. Disruption of technology means changing the realm of life from manual to digital. Kasali (2018) argues that disruption can mean innovation. In the context of the Industrial Revolution 4.0, disruption means changes that are fundamental and massive in the field of information and communication technology that affect every aspect of people's lives. New technological advances that integrate the physical, digital, and biological worlds have influenced all disciplines, economics, industry and government (Fadli et al., 2019).

The Industrial Revolution 4.0 also affects the world of education in Indonesia. The tiger education system does not have to adapt to developments as a result of this revolution. The success of education in the Industrial Revolution 4.0 is determined by the quality of teachers as educators. Furthermore, the ability to adapt to new technology and global challenges is a demand for educators (Lase, 2019). In this digital era, educational institutions need to change literacy orientation, from the old literacy-centered on reading, writing, and arithmetic to new literacy, namely data, technology, and human resources. Data literacy is related to competence in reading, analyzing, and utilizing digital information. Technological literacy is a skill to understand mechanical and technological systems in the professional world. Meanwhile, social and personal competence with character are part of human resource literacy (Lase, 2019).

Meanwhile (Risdianto, 2019) argues, the orientation of educational expertise in this era includes creativity, critical thinking, communication, and collaboration, which is called $4 \mathrm{C}$, namely the skills of students in critical thinking to solve problems, be creative and innovative, and the ability to communicate, and collaborate. In addition, it also requires the ability to search, process, and achieve information, as well as skills in using information and technology. Therefore, the education curriculum in Indonesia must be adaptive to world developments and the changes that occurred in the era of the Industrial Revolution 4.0.

According to Muhadjir Effendy, Minister of Education and Culture for the 2016-2019 Work Cabinet in Indonesia, the expansion of the Industrial Revolution 4.0 into the world of education requires curriculum improvement by prioritizing the competence of students, including: (1) critical thinking; (2) creativity and innovation; (3) interpersonal skills and communication; (4) teamwork and collaboration; and (5) confident (Yusnaini \& Slamet, 2019). Therefore, case-based learning, which is a learning technique that focuses on developing the potential of students in analyzing a case and providing problem solving to the case, can be applied to the learning process. Regarding the implementation of learning in the era of the Industrial Revolution 4.0, the role of teachers cannot be replaced so that educators are needed educational competence; competence in research; competence for digital; competence in globalization; and competence in future straits. In the implementation of learning, the application of the hybrid/blended learning model is highly recommended.

In Indonesia, the curriculum that applies to the primary and secondary levels to date is the 2013 Curriculum. In its development, the 2013 Curriculum has become a policy and was implemented in the 2013/2014 school year. Not long after the inauguration of a new working cabinet under the leadership of President Joko Widodo, the implementation of the 2013 Curriculum was terminated in some schools in Indonesia. The termination occurred because the implementation at that time was only in pilot schools and will be implemented simultaneously in the 2019/2020 school year after a revision is made. This revision process is known to have been completed in 2016 along with the issuance of Regulation of Ministry of Education and Culture (Permendikbud) 20-24 concerning graduate competency standards, content standards, process standards, basic competencies and assessment standards. Education in Indonesia since 2014 can be said to have had standardized guidelines. It was recorded that until 2018, according to the Director General of Teachers and Education Personnel of the Ministry of Education and Culture, there were 78,000 schools that were entering the final stages of implementing the 2013 curriculum (Budi, 2018). This record shows that education in Indonesia from 2014-2020 uses two curriculum standards, namely KTSP and 2013 Curriculum.

Various studies on the implementation of the 2013 curriculum have revealed various problems. Research of Wahyuni \& Wahyuni (2019) reveals that teachers experience many problems in implementing the 2013 Curriculum, namely: (1) the ability of teachers to prepare lesson plans (RPP) based on existing provisions and formats is still lacking; (2) the teacher's ability to implement scientific learning-based learning is still not optimal because of the teacher's understanding still at the initial level and still using traditional learning methods; and (3) the teacher's ability to conduct assessments is still limited to the cognitive aspects so that it ignores the affective and psychomotor aspects of students. This phenomenon is strengthened by research of Hutagalung \& Simarmata (2015), Halim et al. (2019), and Trisianawati et al. (2016) which state that teachers are still teaching using the lecture method in teaching.

Problem solving that can be offered for the above problematics is by optimizing the Subject Teacher Deliberative Forum as a forum for exchanging opinions about difficulties and ways of overcoming difficulties faced in the implementation of 2013 Curriculum learning; optimizing workshop facilities both from schools, regional education offices, and from the province in upgrading teachers' knowledge and creativity 
in designing learning; providing regular training on teaching methods of Science Technology Engineering Arts Mathematics (STEAM).

The implementation of the post-revised 2013 Curriculum is still very relevant to the era of the Industrial Revolution 4.0. The birth of the 2013 Curriculum is a constructive dynamic and is carried out continuously, where the results are logical consequences of the demands of the times. The Ministry of Education and Culture, through the revised 2013 Curriculum formulates 21 st century learning as a new paradigm in educational institutions that emphasizes the ability of students to find out from various sources, formulate problems, think analytically, and collaborate and collaborate in solving problems (Litbang Kemdikbud, 2013). The 21st century learning framework is formulated in $4 \mathrm{C}$ skills, including critical thinking and problem-solving skills, communication and collaboration skills, creativity and innovation skills. Information and communication technology literacy as well as strengthening character education in character building and spiritual values are also developed in the 2013 Curriculum (BSNP, 2010).

\subsection{Curriculum of the Pandemic of Covid-19 Era}

At the end of 2019, not only Indonesia, but countries in the world were shocked by the emergence of an infectious disease that attacks the respiratory tract thought to have originated in Wuhan. The World Health Organization (WHO) officially announced on 11 February 2020 that this contagious disease was named Corona Virus Disease (Covid-19) (Setyorini, 2020). The people most at risk of contracting this virus are those who are in close contact with Covid-19 patients (Indonesian Ministry of Health, 2020).

Initially in Indonesia, the spread of this virus only occurred in certain areas. In order to anticipate the spread of viruses and cases of infection in Indonesia so that they do not become more widespread, the government has issued a new policy, namely by applying the principles social distancing at all levels of society. Even in several big cities in Indonesia, PSBB (Pembatasan Sosial Berskala Besar/Large Scale Social Restrictions) have been implemented to break the chain of spreading this virus (Setyorini, 2020). The Covid-19 pandemic has had a huge impact on life in society, especially in the field of education. So that on March 18, 2020 the government issued a circular letter which stated that all activities carried out, both indoors and outdoors in all sectors were temporarily postponed, especially in the field of education (Rosali, 2020).

The government through the Ministry of Education and Culture has made various learning adjustments that do not burden educators and students. These adjustments are contained in Circular Letter Number 2 of 2020 concerning Prevention and Handling of Covid-19 within the Ministry of Education and Culture and Circular Letter Number 3 of 2020 concerning Prevention of Covid-19 in the Education Unit (Rozuna, 2020). Not only that, a series of other policies were issued to address the development of the spread of Covid-19, such as the cancellation of the 2020 National Examination, adjustment of school exams that did not need to measure curriculum completeness, implementation of distance learning, and mechanisms for the admission process of new students according to Circular Letter Number 4 of 2020 concerning Implementation of Education Policies in an Emergency Period of Corona Virus Diseases 19 (Covid-19)

In addition, there is a policy to adjust the use of school operational assistance (Bantuan Operasional Sekolah) and flexible education operational assistance to meet school needs during the pandemic. As conveyed by the Minister of Education and Culture at a coordination meeting with four ministers, the principle of education policy during the Covid-19 pandemic was to prioritize the health and safety of students, educators, education personnel, families, and society in general, and to consider the growth and development of students and psychosocial conditions are also a consideration in efforts to fulfill educational services during the Covid-19 pandemic.

To anticipate the negative consequences and issues of distance learning, then the government implemented two new policies, namely the expansion of face-to-face learning for the yellow zone and the imposition of an emergency curriculum (under special conditions). Faceto-face learning is allowed for all levels in the green and yellow zones. Schools are given the freedom to choose a curriculum that suits the learning needs of students during a pandemic, as stipulated in the Decree of the Minister of Education and Culture regarding curricula during an emergency.

In the revision of the Joint Decree of the Four Ministers issued on August 7, 2020, face-to-face learning of students who are in the green and yellow zones is allowed, but it is not mandatory. For areas in the orange and red zones, face-to-face learning is still prohibited in each educational unit. At the primary and secondary education levels, face-to-face learning can be started simultaneously by considering the health risks that do not differ between levels. Meanwhile, for early childhood education programs can start face-to-face learning no later than 2 months after the primary and secondary levels. To alleviate difficulties in learning during the Covid-19 period, an emergency curriculum and learning modules can be used.

Emergency curriculum (in special conditions) is a simplification of competencies that refers to the 2013 curriculum. Simplification of basic competencies for 
each subject so that teachers can focus on teaching essential competencies and prerequisites for continuing learning at the next level. The implementation of the curriculum in special conditions aims to provide flexibility for educational units to determine the curriculum according to the learning needs of students. The Minister of Education and Culture explained that each education unit can choose from 3 options in implementing the curriculum, namely: (1) continue to use the 2013 Curriculum; (2) using the emergency curriculum (in special conditions); or (3) conducting curriculum simplification independently.

In addition, to support the success of learning during the Covid-19 pandemic, the government has also relaxed regulations for teachers, namely teachers are no longer required to fulfill 24-hour workloads face-to-face in one week as stated in the Decree of the Minister of Education and Culture Number 719/P/2020 concerning Guidelines for Implementing Curriculum in Education Units in Special Conditions so that teachers can focus on providing interactive lessons to students without the need to pursue hours. This is not enough for the success of learning during the Covid-19 pandemic, but there is a need for comprehensive cooperation from all parties including parents, teachers, schools, government, health services, and also the community.

The current situation and condition of the Covid-19 pandemic cannot be predicted, when it will end. Therefore, leaders in educational institutions must take careful steps in carrying out the transformation of the education system in schools. The government has provided a policy in the form of a curriculum in special conditions that can make it easier for teachers to implement Distance Learning, without having to wait for further instructions from the central government, schools should have a careful backup plan in educating their students.

Transforming the education system is indeed not easy, it needs at least three main types of ideas in Survival Innovation namely: (1) Digital Innovation in the form of information integration in education in schools. This innovation must be realized in a structured and systematic manner and there must be digital innovation in the form of online education to be an integral component of the hybrid education model in schools. Digital innovation does not always mean online learning, but can also take the form of offline applications with various strategies for delivering material in the form of digital content-based especially for learning in areas that are not well covered by the internet; (2) Collaboration Innovation is a pool of resources and strengths through collaboration and co-creation; (3) Business Innovation model, schools can innovate business processes in the form of online learning (online-schooling) using a digital platform (Kompasiana, 2020). Through the idea of Survival Innovation, a hybrid education model can be proposed which is an integral part of the Indonesian education system, where offline learning traditional and e-learning can work during the Covid-19 pandemic.

\section{CONCLUSION}

Based on the discussion that has been described, it can be concluded that the implementation of the postrevised 2013 Curriculum is still very relevant to the era of the Industrial Revolution 4.0. The 21st century learning framework is formulated in $4 \mathrm{C}$ skills, including: critical thinking and problem-solving skills, communication and collaboration skills, creativity and innovation skills. Information and communication technology literacy and strengthening character education in character development (character building) and spiritual values are also developed in the 2013 Curriculum.

Emergency curriculum (in special conditions) is a simplification of competencies that refers to the 2013 Curriculum. The basic competencies simplification for each subject so that teachers can focus on teaching essential competencies and prerequisites for continuing learning at the next level. Common challenges in the field of education in the digital era must be faced and addressed by all education stakeholders in this country. Collaboration from all stakeholders is the key to accelerating digital literacy at this time. Because digital literacy skills indicate this nation is ready to face the era of the Industrial Revolution 4.0, especially when we are faced with unexpected calamities such as the Covid-19 pandemic, where we are very dependent on the digital world.

\section{REFERENCES}

[1] BNSP. 2010. Panduan Pengembangan Indikator. Jakarta: Kemendiknas.

[2] Budi, K. (2018). Penerapan Kurikulum 2013, Sekolah mesti Dukung Pengembangan Materi. Kompas.com (online).

[3] Demonika, S. D., Mustadi, A., \& Rezkillah, I. I. (2020). Implementasi Tematik Integratif Kurikulum 2013 di Sekolah Dasar. Jurnal Pendidikan, 5, 817-821.

[4] Fadli, R. P., Ifdil, I., \& Amalianita, B. (2019). Peluang dan Tantangan Bimbingan Karir di Sekolah Menengah Kejuruan pada Era Revolusi Industri 4.0, 102-108.

[5] Ghufron, M. A. (2018). Revolusi industri 4.0: Tantangan, Peluang dan Solusi bagi Dunia Pendidikan, 332-337.

[6] Halim, S., Boleng, D. T., \& Labulan, P. (2019). Pengaruh Model Pembelajaran Discovery Learning dan Number Head Together terhadap Aktivitas, Motivasi, dan Hasil Belajar Siswa. Jurnal Pijar MIPA, 14, 55-61.

[7] Hutagalung, A., \& Simarmata, U. (2015). Pengaruh Model Pembelajaran Kooperatif Tipe Group Investigation terhadap Hasil Belajar Siswa. INPAFI (Inovasi Pembelajaran $\quad$ Fisika), 3(1) https://doi.org/10.24114/inpafi.v3i1.8015

[8] Kemendikbud. (2020). Revisi Surat Keputusan Bersama (SKB) Menteri Pendidikan dan Kebudayaan, Menteri 
Agama, Menteri Kesehatan, dan Menteri dalam Negeri RI Nomor $03 / \mathrm{KB} / 2020$ Nomor 612 Tahun 2020 Nomor HK.01.08/Menkes/502/2020 Nomor 119/4536/SJ Tentang Panduan Penyelenggaraan Penyelenggaraan Pembelajaran pada Tahun Ajaran 2020/2021 di Masa Pandemi Coronavirus Disease 2019 (Covid-19).

[9] Kemendikbud. (2020). Surat Edaran (SE) Nomor 4 Tahun 2020 Tentang Pelaksanaan Kebijakan Pendidikan dalam Masa Darurat Penyebaran Corona Virus Desease (Covid19).

[10] Kemendikbud. (2020). Keputusan Menteri Pendidikan dan Kebudayaan RI Nomor 719/P/2020 Tentang Pedoman Pelaksanaan Kurikulum pada Satuan Pendidikan dalam Kondisi Khusus.

[11] Kemenkes RI. (2020). Pedoman Pencegahan dan Pengendalian Corona Virus Disease (Covid-19). Jakarta: Dirjen Pencegahan dan Pengendalian Penyakit.

[12] Kompasiana. (2020). Dilema Perubahan Paradigma Pendidikan Indonesia pada masa Disrupsi Covid-19. Kompasiana.com (online).

[13] Lase, D. (2019). Pendidikan di Era Revolusi Industri 4.0. Jctes, 1(1), 28-43.

[14] Prajana, A., \& Astuti, Y. (2020). Pemanfaatan Teknologi Informasi dan Komunikasi dalam Pembelajaran oleh Guru SMK Di Banda Aceh dalam Upaya Implementasi Kurikulum 2013. JINOTEP (Jurnal Inovasi dan Teknologi Pembelajaran): Kajian dan Riset dalam Teknologi Pembelajaran, 7(1), 33-41. https://doi.org/10.17977/um031v7i12020p033

[15] Prasetyo, B., \& Trisyanti, U. (2018). Revolusi Industri 4.0 dan Tantangan Perubahan Sosial, 5, 22-27. https://doi.org/10.12962/j23546026.y2018i5.4417

[16] Risdianto, E. (2019). Analisis Pendidikan Indonesia di Era Revolusi Industri 4.0. Center for American Progress, 1.

[17] Rosali, E. S. (2020). Aktifitas Pembelajaran Daring pada Masa Pandemi Covid-19 di Jurusan Pendidikan Geografi Universitas Siliwangi Tasikmalaya. Geography Science Educational Journal (GEOSEE), 1(1), 21-30.

[18] Rozuna. (2020). Imbauan Mendikbud terkait Pencegahan Penyebaran Covid-19.

[19] Setyorini. (2020). Pandemi Covid-19 dan Online Leraning: Apakah Berpengaruh terhadap Proses Pembelajaran pada Kuriulum 13. Journal of Industrial Engineering \& Management Research (JIEMAR), 1(1), 95-102.

[20] Subhi, I. (2020). Urgensi Upaya Menjaga Mutu Pembelajaran di Tengah Pandemi Covid 19. Journal of Chemical Information and Modeling, 3(1), 1689-1699.

[21] Taufiq, A. D., \& Rijanto, T. (2020). Evaluasi Impelementasi Kurikulum 2013: Studi Kasus Program Keahlian Teknik Ketenagalistrikan. Jurnal Pendidikan Teknik Elektro, 9(2), 341-348.

[22] Trisianawati, E., Djudin, T., \& Setiawan, R. (2016). Pengaruh Model Pembelajaran Kooperatif Tipe Jigsaw terhadap Hasil Belajar Siswa pada Materi Vektor di Kelas $X$ SMA Negeri 1 Sanggau Ledo. Jurnal Penelitian Fisika dan Aplikasinya (JPFA), 6(2), 51. https://doi.org/10.26740/jpfa.v6n2.p51-60

[23] Wahyuni, B., \& Wahyuni, R. (2019). Problematika Implementasi Kurikulum 2013 di Sekolah Dasar. Jurnal Manajemen dan Supervisi Pendidikan, 3, 63-68.

[24] Yusnaini, \& Slamet. (2019). Era Revolusi Industri 4.0: Tantangan dan Peluang dalam Upaya Meningkatkan Literasi Pendidikan. Prosiding Seminar Nasional
Pendidikan Program Pascasarjana Universitas Pgri Palembang, 2, 1073-1085.

[25] Kusumaningrum, D. E., Sumarsoso, R. B., \& Gunawan, I. (2019). Budaya Sekolah dan Etika Profesi: Pengukuran Pemberdayaan Sumber Daya Manusia Sekolah dengan Pendekatan Soft System Methodology. JAMP: Jurnal Administrasi dan Manajemen Pendidikan, 2(3), 90-97.

[26] Gunawan, I. (2012, May). Mengembangkan Karakter Bangsa Berdasarkan Kearifan Lokal. In Prosiding Seminar Nasional Meretas Sekolah Humanis untuk Mendesain Siswa Sekolah Dasar yang Cerdas dan Berkarakter, PGSD FKIP Universitas Muhammadiyah Surakarta, hlm (Vol. 50).

[27] Kusumaningrum, D. E., Arifin, I., \& Gunawan, I. (2017). Pendampingan pengembangan perangkat pembelajaran berbasis Kurikulum 2013. ABDIMAS PEDAGOGI Jurnal Ilmiah Pengabdian kepada Masyarakat, 1(1).

[28] Gunawan, Imam, and Rina Tri Sulistyoningrum. "Menggali Nilai-Nilai Keunggulan Lokal Kesenian Reog Ponorogo Guna Mengembangkan Materi Keragaman Suku Bangsa Dan Budaya Pada Mata Pelajaran IPS Kelas IV Sekolah Dasar." Premiere Educandum: Jurnal Pendidikan Dasar dan Pembelajaran 3.01 (2016).

[29] Kusumaningrum, D. E., Sumarsono, R. B., \& Gunawan, I. (2017). Problematika Pemberdayaan dan Pengembangan Sumber Daya Manusia di Sekolah Menengah Pertama Berbasis Pesantren. Ilmu Pendidikan: Jurnal Kajian Teori dan Praktik Kependidikan, 2(2), 139 150.

[30] Pertiwi, A. K., Cahyani, S. S. A., Diana, R. C., \& Gunawan, I. (2018, October). The Leadership of Kyai: A Descriptive Study. In 3rd International Conference on Educational Management and Administration (CoEMA 2018). Atlantis Press

[31] Bafadal, I., Nurabadi, A., Sobri, A. Y., \& Gunawan, I. (2019). The Competence of Beginner Principals as Instructional Leaders in Primary Schools. International Journal of Innovation, Creativity and Change, 5(4), 625639.

[32] Kusumaningrum, D. E., Sumarsono, R. B., \& Gunawan, I. (2018, October). Empowering the Principal of Boarding House-Based Junior High School in East Java Province Indonesia. In 3rd International Conference on Educational Management and Administration (CoEMA 2018). Atlantis Press.

[33] Nurabadi, A., Sucipto, S., Juharyanto, J., \& Gunawan, I. (2018, October). The Implementation of Education Management Standards in the School Laboratory State University of Malang for Improving Educational Quality. In 3rd International Conference on Educational Management and Administration (CoEMA 2018). Atlantis Press.

[34] Agustina, N. E., Sumarsono, R. B., \& Gunawan, I. (2018, September). Implementation of School and Community Relationship Techniques (A Case Study in SDN Karangbesuki 2 Malang, Indonesia). In 1st International Conference on Early Childhood and Primary Education (ECPE 2018). Atlantis Press.

[35] Sultoni, S., Gunawan, I., \& Ningsih, S. O. (2018, October). Descriptive Study of Efforts Integrates Character Values to Students. In 3rd International Conference on Educational Management and Administration (CoEMA 2018). Atlantis Press.

[36] Gunawan, I. (2016). Pengantar Statistika Inferensial. Jakarta: Rajawali Pers. 